\title{
Importance-performance analysis: A comparative study of motor repair service customers
}

\author{
C. Boshoff \\ Department of Business Economics, Vista University, Port Elizabeth
}

\begin{abstract}
At least two American studies have found that a high percentage of new car owners do not return to the dealership they purchased their vehicle from for servicingl repairs after the initial warranty had expired. Patronage seems to have shifted to the so-called independent workshops. It appears as if the same trend prevails in South Africa and should be a source of concern to vehicle manufacturers. The study described in this article attempted to identify possible reasons for this shift in patronage and also to establish whether market requirements in general are being satisfied by these institutions. The results obtained indicate that independent workshops perform certain attributes of a motor repair service that are important to consumers markedly better than franchised dealerships do. It was further established that neither institution currently fully satisfies market requirements. S. Afr. J. Bus. Momt. 1986, 17: 196- 201
\end{abstract}

Ten minste twee Amerikaanse studies het bevind dat 'n hoe persentasie van nuwe voertuigeienaars nie na die agentskap waar hulle hul voertuig aanvanklik gekoop het terugkeer vir herstel- en versieningsdienste nadat die waarborgperiode op die voertuig verstryk het nie. Ondersteuning verskuif skynbaar na die sogenaamde onafhanklike diensstasie. Die vermoede bestaan dat dieselfde neiging ook in Suid.Afrika voorkom en behoort 'n bron van kommer vir motor. vervaardigers te wees. Die ondersoek waarvan hierdie artikel verslag lewer was gemik daarop om moontlike redes vir die verskuiwing te identifiseer en ook om te bepaal of beide instellings tans daarin slaag om markbehoeftes te bevredig. Die verkre resultate dui daarop dat onafhanklike diensstasies sekere aspekte van 'n motorhersteldiens wat vir verbruikers belangrik is merkbaar beter verrig as agentskaphouers. Verder is bevind dat nie een van die instellings tans werklik daarin slaag om markbehoeftes te bevredig nie.

S.Afr. Tydskr. Bednfsl. 1986, 17: 196-201

\section{Introduction}

At least two American studies have found that a high percentage of new car owners do not return to the dealership they purchased their vehicle from for servicing/repairs after the initial warranty had expired. Patronage seems to have shifted to the so-called independent workshops. (Richardson \& Fogg, 1970:217; Crandall, 1970:19). The continuation of this trend in later years has been confirmed by Moyer \& Whitmore (1976:37) and in South Africa by Pretorius (1973: 28). Further possible evidence thereof is that at least two South African manufacturers estimate their customer retention rate after the expiry of the warranty on new vehicles, at below $30 \%{ }^{1}$. This situation is a source of concern throughout the industry ${ }^{2}$.

In this study the objective will be to compare the perceptions of customers of franchised motor dealerships and independent repair workshops regarding certain attributes of a motor repair service. This will be done to determine whether independent workshops perform certain attributes of a motor repair service that are important to consumers better than franchised dealerships do. If found to be true, this could elucidate possible reasons for the low retention rate of franchised dealerships. An attempt will also be made to establish whether both institutions succeed in satisfying market requirements with regard to specific attributes.

\section{Methodology}

An importance-performance analysis as suggested by Martilla \& James (1977) was used to determine the perceptions of respondents regarding 21 attributes of a motor repair service. Respondents were asked two questions regarding each attribute namely:

- How important is this attribute? - measuring market requirements.

- How well does the workshop which repairs your vehicle, perform the attribute? - measuring current attempts to satisfy market requirements.

Twelve of the 14 attributes identified by Martilla \& James (1977) were used whereas a further eight were identified and added after a focus group session with vehicle owners and consultations with managers in the motor industry. The complete list of attributes used in the study appears in Table 2.

The data collection instruments used were two four-point scales. Importance could be rated on a four-point scale: extremely important (value 4), important (value 3), slightly important (value 2), and not important (value 1). Performance could also be rated on a four-point scale: excellent (4), good
Department of Business Economies, Vista University, Private Bag X613, Port Elizabeth, 6000 Republic of South Africa 
Table 1 Size and composition of the respondent group

\begin{tabular}{|c|c|c|c|c|}
\hline \multirow[b]{2}{*}{$\begin{array}{l}\text { Elements of } \\
\text { respondent group }\end{array}$} & \multirow[b]{2}{*}{$\begin{array}{l}\text { Sample } \\
\text { size }\end{array}$} & \multirow[b]{2}{*}{$\begin{array}{l}\text { Number } \\
\text { of } \\
\text { responses }\end{array}$} & \multicolumn{2}{|c|}{$\begin{array}{l}\text { Responses as } \\
\text { percentage of }\end{array}$} \\
\hline & & & $\begin{array}{c}\text { Total } \\
\text { number } \\
\text { of } \\
\text { responses }\end{array}$ & $\begin{array}{c}\text { Total } \\
\text { sample } \\
\text { size }\end{array}$ \\
\hline $\begin{array}{l}\text { Customers of } \\
\text { franchised dealerships }\end{array}$ & 330 & 185 & 55,9 & 28,03 \\
\hline $\begin{array}{l}\text { Customers of } \\
\text { independent workshops } \\
\text { Total }\end{array}$ & $\begin{array}{l}330 \\
660\end{array}$ & $\begin{array}{l}146 \\
331\end{array}$ & $\begin{array}{c}44,1 \\
100 \%\end{array}$ & $\begin{array}{l}22,12 \\
50,15 \%\end{array}$ \\
\hline
\end{tabular}

(3), fair (2) and poor (1). A 'no basis for judgement' category was also provided. A mean rating for each attribute was then calculated.

The research utilized a mail questionnaire. The sample consisted of two groups of randomly selected respondents: customers of franchised dealerships and customers of independent workshops. Three hundred and thirty questionnaires were mailed to each group. Three hundred and thirtyone of the 660 questionnaires were returned in usable form after one telephonic follow-up, for a response rate of $50,15 \%$.

The size and composition of the respondent group is shown in Table 1.

With regard to reporting response rates, Berdie \& Anderson (1976:72 - 73) argued that studies using mail questionnaires as research method, should give an indication of the response rate per item on the questionnaire. This will allow the reader to decide whether data obtained are generalizable to the population represented by the sample studied.

All the questions in the section of the questionnaire measuring the importance of 21 attributes of a motor repair service, were answered. The section measuring performance, however, allowed for a 'no basis for judgement' alternative as an answer. These responses were awarded a value of zero and excluded from the computation of mean values. As the excessive use of this alternative could have an influence on the reliability of the mean values of certain attributes, the item response rate per respondent group is shown in Table 2.

Table 2 shows a relatively low response rate (answers marked 'no basis for judgement') on three items by customers of franchised dealerships. These are the availability of substitute transport $(73,5 \%)$, the sending out of regular reminder or maintenance notices $(72,4 \%)$, and being informed in time if the vehicle repaired must stay overnight $(74,6 \%)$. Even lower response rates were recorded for customers of independent workshops regarding location close to work $(74,7 \%)$ availability of substitute transport $(61,6 \%)$ and the sending out of regular reminder or maintenance notices $(58,9 \%)$.

\section{Empirical investigation and analysis \\ A comparison of importance ratings}

In Table 3 a comparison is made between the importance ratings of both respondent groups in an attempt to determine whether significant differences regarding the importance of certain attributes do exist.

From Table 3 it would appear as though the needs and requirements of both respondent groups are largely similar, as the importance ratings of individual attributes by both groups do not differ significantly $(P<0,05)$. The only exceptions are the greater need of customers of franchised dealerships regarding the availability of spare parts and their need to be

Table 2 Item response rate per respondent group

Attributes in order of appearance on questionnaire
Respondent groups

\begin{tabular}{|c|c|c|c|c|c|c|c|}
\hline \multicolumn{4}{|c|}{ Customers of franchised dealerships } & \multicolumn{4}{|c|}{ Customers of independent workshops } \\
\hline \multicolumn{2}{|c|}{$\begin{array}{l}\text { Importance } \\
\text { evaluation }\end{array}$} & \multicolumn{2}{|c|}{$\begin{array}{c}\text { Performance } \\
\text { evaluation }\end{array}$} & \multicolumn{2}{|c|}{$\begin{array}{l}\text { Importance } \\
\text { evaluation }\end{array}$} & \multicolumn{2}{|c|}{$\begin{array}{l}\text { Performance } \\
\text { evaluation }\end{array}$} \\
\hline $\begin{array}{l}\text { Number of } \\
\text { responses }\end{array}$ & $\begin{array}{l}\% \text { of } \\
\text { total }\end{array}$ & $\begin{array}{l}\text { Number of } \\
\text { responses }\end{array}$ & $\begin{array}{l}\% \text { of } \\
\text { total }\end{array}$ & $\begin{array}{l}\text { Number of } \\
\text { responses }\end{array}$ & $\begin{array}{l}\% \text { of } \\
\text { total }\end{array}$ & $\begin{array}{l}\text { Number of } \\
\text { responses }\end{array}$ & $\begin{array}{l}\% \text { of } \\
\text { total }\end{array}$ \\
\hline 185 & 100 & 183 & 98,9 & 146 & 100 & 146 & 100 \\
\hline 185 & 100 & 182 & 98,4 & 146 & 100 & 144 & 98,6 \\
\hline 185 & 100 & 176 & 95,1 & 146 & 100 & 140 & 95,9 \\
\hline 185 & 100 & 184 & 99,5 & 146 & 100 & 144 & 98,6 \\
\hline 185 & 100 & 185 & 100 & 146 & 100 & 146 & 100 \\
\hline 185 & 100 & 185 & 100 & 146 & 100 & 146 & 100 \\
\hline 185 & 100 & 172 & 93,0 & 146 & 100 & 139 & 95,2 \\
\hline 185 & 100 & 173 & 93,5 & 146 & 100 & 138 & 94,5 \\
\hline 185 & 100 & 178 & 96,2 & 146 & 100 & 144 & 98,6 \\
\hline 185 & 100 & 158 & 85,4 & 146 & 100 & 140 & 95,9 \\
\hline 185 & 100 & 158 & 85,4 & 146 & 100 & 109 & 74,7 \\
\hline 185 & 100 & 136 & 73,5 & 146 & 100 & 90 & 61,6 \\
\hline 185 & 100 & 134 & 72,4 & 146 & 100 & 86 & 58,9 \\
\hline 185 & 100 & 142 & 76,8 & 146 & 100 & 129 & 88,4 \\
\hline 185 & 100 & 171 & 92,4 & 146 & 100 & 141 & 96,6 \\
\hline 185 & 100 & 171 & 92,4 & 146 & 100 & 145 & 99,3 \\
\hline 185 & 100 & 165 & 89,2 & 146 & 100 & 112 & 76,7 \\
\hline 185 & 100 & 176 & 95,1 & 146 & 100 & 126 & 86,3 \\
\hline 185 & 100 & 138 & 74,6 & 146 & 100 & 130 & 89,0 \\
\hline 185 & 100 & 178 & 96,2 & 146 & 100 & 144 & 98,6 \\
\hline 185 & 100 & 151 & 81,6 & 146 & 100 & 137 & 93,8 \\
\hline
\end{tabular}


properly informed by means of clear signs where reception is, where to park, where to pay accounts, etc. However, a Hotellings square test was conducted which revealed that this was not the case. Customers of independent workshops do differ, compared to customers of franchised dealerships, in their evaluation of the importance of these attributes as a

Table 3 Importance ratings of attributes: Both respondent groups

\begin{tabular}{|c|c|c|c|c|}
\hline \multirow{3}{*}{ 总 } & \multirow{3}{*}{ Attribute } & \multicolumn{2}{|c|}{ Importance ratings } & \multirow{3}{*}{$\begin{array}{c}\text { Differences }^{b} \\
\text { (A-B) } \\
\text { (C) }\end{array}$} \\
\hline & & \multirow{2}{*}{$\begin{array}{l}\text { Franchised } \\
\text { dealership } \\
\text { customers } \\
\text { (A) }\end{array}$} & \multirow{2}{*}{$\begin{array}{l}\text { Independent } \\
\text { workshop } \\
\text { customers } \\
\text { (B) }\end{array}$} & \\
\hline & & & & \\
\hline 1 & Job done right the first time & 3,92 & 3,88 & $+0,04$ \\
\hline 2 & Fast response to complaints & 3,54 & 3,60 & $-0,06$ \\
\hline 3 & Able to do any job needed & 3,35 & 3,19 & $+0,16$ \\
\hline 4 & Service available when needed & 3,37 & 3,35 & $+0,02$ \\
\hline 5 & Courteous and friendly service & 3,28 & 3,29 & $-0,01$ \\
\hline 6 & Vehicle ready when promised & 3,57 & 3,58 & $-0,01$ \\
\hline 7 & Perform only necessary work & 3,21 & 3,42 & $-0,21$ \\
\hline 8 & Reasonable prices & 3,54 & 3,64 & $-0,10$ \\
\hline 9 & Honesty - work indicated as completed must be completed & 3,95 & 3,88 & $+0,07$ \\
\hline 10 & Conveniently close to home & 2,01 & 2,26 & $-0,25$ \\
\hline 11 & Conveniently close to work & 2,30 & 2,03 & $+0,27$ \\
\hline 12 & Availability of substitute transport & 2,48 & 2,27 & $+0,21$ \\
\hline 13 & Regular reminder/maintenance notices & 2,05 & 1,86 & $+0,19$ \\
\hline 14 & Accurate quotations & 3,40 & 3,40 & 0,00 \\
\hline 15 & Fast service on minor repairs & 3,30 & 3,19 & $+0,11$ \\
\hline 16 & Availability of spare parts & 3,58 & 3,37 & $+0,21^{4}$ \\
\hline 17 & Clean attractive waiting room & 2,56 & 2,41 & $+0,15$ \\
\hline 18 & Clear signs e.g. reception, parking etc. & 2,70 & 2,40 & $+0,30^{n}$ \\
\hline 19 & Informed in time of overnight stay & 3,60 & 3,44 & $+0,16$ \\
\hline 20 & Availability of informative account & 3,58 & 3,58 & 0,00 \\
\hline 21 & Personal contact with mechanic & 2,92 & 3,00 & $-0,08$ \\
\hline
\end{tabular}

Significant at $P<0,05$.

${ }^{b} A$ positive coefficient in column $C$ indicates that the importance rating of franchised dealership customers exced the importance rating of customers of independent workshops regarding that particular attribute, and vice versa.

Table $4^{\circ}$ Performance ratings of attributes: Both respondent groups

\begin{tabular}{|c|c|c|c|c|}
\hline \multirow{3}{*}{ 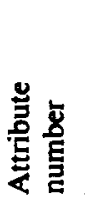 } & \multirow{3}{*}{ Attribute } & \multicolumn{2}{|c|}{ Performance ratings } & \multirow{3}{*}{$\begin{array}{c}\text { Differences } \\
\begin{array}{c}\text { (A-B) } \\
\text { (C) }\end{array}\end{array}$} \\
\hline & & \multirow{2}{*}{$\begin{array}{l}\text { Franchised } \\
\text { dealership } \\
\text { customers } \\
\text { (A) }\end{array}$} & \multirow{2}{*}{$\begin{array}{l}\text { Independent } \\
\text { workshop } \\
\text { customers } \\
\text { (B) }\end{array}$} & \\
\hline & & & & \\
\hline 1 & Job done right the first time & 2,36 & 2,86 & $-0,50^{2}$ \\
\hline 2 & Fast response to complaints & 2,63 & 3,04 & $-0,41^{*}$ \\
\hline 3 & Able to do any job needed & 2,81 & 2,81 & $0, \infty 0$ \\
\hline 4 & Service available when needed & 2,83 & 2,98 & $-0,15$ \\
\hline 5 & Courteous and friendly service & 3,02 & 3,35 & $-0,33^{2}$ \\
\hline 6 & Vehicle ready when promised & 2,63 & 2,97 & $-0,34^{2}$ \\
\hline 7 & Perform only necessary work & 2,84 & 3,06 & $-0,22$ \\
\hline 8 & Reasonable prices & 2,13 & 2,61 & $-0,48^{2}$ \\
\hline 9 & Honesty - work indicated as completed must be completed & 2,50 & 2,86 & $-0,36^{*}$ \\
\hline 10 & Conveniently close to home & 1,93 & 2,86 & $-0,93^{2}$ \\
\hline 11 & Conveniently close to work & 2,22 & 2,40 & $-0,18$ \\
\hline 12 & Availability of substitute transport & 1,87 & 1,72 & $+0,15$ \\
\hline 13 & Regular reminder/maintenance notices & 1,71 & 1,36 & $+0,35$ \\
\hline 14 & Accurate quotations & 2,47 & 2,71 & $-0,24$ \\
\hline 15 & Fast service on minor repairs & 2,62 & 3,09 & $-0,47^{2}$ \\
\hline 16 & Availability of spare parts & 2,70 & 2,52 & $+0,18$ \\
\hline 17 & Clean attractive waiting room & 2,68 & 2,40 & $+0,28$ \\
\hline 18 & Clear signs e.g. reception, parking etc. & 2,73 & 2,44 & $+0,29^{a}$ \\
\hline 19 & Informed in time of overnight stay & 2,46 & 2,95 & $-0,49^{2}$ \\
\hline 20 & Availability of informative account & 2,91 & 3,10 & $-0,19$ \\
\hline 21 & Personal contact with mechanic & 2,17 & 3,26 & $-1,09^{\circ}$ \\
\hline
\end{tabular}

Significant at $P<0,05$.

${ }^{b} A$ positive coefficient in column $C$ indicates that the performance rating of franchised dealership customers exced the performance rating of customers of independent workshops regarding that particular attribute, and vice versa. 
whole, although this is not the case with the majority of individual attributes.

\section{A comparison of performance ratings}

The performance ratings of both respondent groups, per attribute, are shown in Table 4.

It is apparent from Table 4 that the performance ratings (mean values) of independent workshops by their customers exceed the performance ratings of franchised dealerships by their customers regarding 15 attributes. Of these differences, 10 are significant at the $P<0,05$ level. They are:

1. Job done right the first time.

2. Fast response to complaints.

5. Courteous and friendly service.

6. Vehicle ready when promised.

8. Reasonable prices.

9. Honesty - work indicated as completed must be completed.

10. Conveniently close to home.

15. Fast service on minor repairs.

19. Informed in time of overnight stay.

21. Personal contact with mechanic.

Of these 10 attributes all, except 'conveniently close to home' (10), are regarded as important (rated at a mean value of three or more) ${ }^{3}$ by customers of independent workshops. The importance ratings of customers of franchised dealerships were largely similar except for the attribute 'personal contact with mechanic', which was rated slightly lower at a mean value of 2,92 but is also regarded as important for purposes of this study (see Table 3).

Table 4 also shows that the performance ratings of franchised dealerships by their customers exceed the performance ratings of independent workshops by their customers regarding five attributes. However, only the difference regarding the attribute 'clear signs e.g. reception, parking etc.' is significant at the $P<0,05$ level, and is not regarded as important by either respondent group (see Table 3).

To summarize, independent workshops outperform franchised dealerships to a significant degree regarding nine important attributes of a motor repair service. Franchised dealerships, on the other hand outperform independent workshops regarding one attribute, which is not regarded as important by either respondent group.

\section{Importance-performance ratings: customers of franchised dealerships}

The importance and performance ratings of customers of franchised dealerships are shown in Table 5. Ranking is in descending order of importance.

Table 5 reveals that of the 15 attributes most important to customers of franchised dealerships, importance ratings exceed performance ratings to a significant degree in all instances. On the other hand performance exceed importance for only two attributes but neither are regarded as important (mean values of three and higher are regarded as important), nor are the differences significant at the $P<0,05$ level. This would seem to indicate that franchised dealerships do not satisfy the needs and requirements of customers regarding important attributes of a repair service.

\section{Importance-performance ratings: customers of independent workshops}

Importance-performance ratings of customers of independent workshops are shown in Table 6. Ranking is in descending order according to mean importance values.

Table 6 reveals that of the 15 attributes most important to customers of independent workshops, importance ratings exceed performance ratings to a significant degree in 12 cases. Performance exceeds importance for only five attributes of which only one is significant at the $P<0,05$ level. This would

Table 5 Importance and performance ratings of attributes: Customers of franchised dealerships

\begin{tabular}{|c|c|c|c|c|c|}
\hline \multirow{2}{*}{ 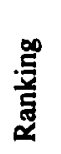 } & \multirow{2}{*}{ 岁 } & \multirow{2}{*}{ Attribute } & \multirow{2}{*}{$\begin{array}{l}\text { Mean } \\
\text { importance } \\
\text { rating } \\
\text { (A) }\end{array}$} & \multirow{2}{*}{$\begin{array}{l}\text { Mean } \\
\text { performance } \\
\text { rating } \\
\text { (B) }\end{array}$} & \multirow{2}{*}{$\begin{array}{c}\text { Difference }^{\mathrm{b}} \\
\text { (B) }- \text { (A) } \\
\text { (C) }\end{array}$} \\
\hline & & & & & \\
\hline 1 & 9 & Honesty - work indicated as completed must be completed & 3,95 & 2,46 & $-1,49^{2}$ \\
\hline 2 & 1 & Job done right the first time & 3,92 & 2,36 & $-1,56^{\mathrm{a}}$ \\
\hline 3 & 19 & Informed in time of overnight stay & 3,60 & 2,46 & $-1,14^{2}$ \\
\hline 4 & 16 & Availability of spare parts & 3,58 & 2,70 & $-0,88^{2}$ \\
\hline 5 & 20 & Availability of an informative account & 3,58 & 2,91 & $-0,67^{2}$ \\
\hline 6 & 6 & Vehicle ready when promised & 3,57 & 2,63 & $-0,94^{\mathrm{a}}$ \\
\hline 7 & 8 & Reasonable prices & 3,54 & 2,13 & $-1,41^{\mathrm{a}}$ \\
\hline 8 & 2 & Fast response to complaints & 3,53 & 2,63 & $-0,90^{2}$ \\
\hline 9 & 14 & Accurate quotations & 3,40 & 2,47 & $-0,93^{2}$ \\
\hline 10 & 4 & Service available when needed & 3,37 & 2,83 & $-0,54^{n}$ \\
\hline 11 & 3 & Able to do any job needed & 3,35 & 2,81 & $-0,54^{2}$ \\
\hline 12 & 15 & Fast service on minor repairs & 3,30 & 2,62 & $-0,68^{*}$ \\
\hline 13 & 5 & Courteous and friendly service & 3,28 & 3,02 & $-0,26^{2}$ \\
\hline 14 & 7 & Perform only necessary work & 3,21 & 2,84 & $-0,37^{a}$ \\
\hline 15 & 21 & Personal contact with mechanic & 2,92 & 2,17 & $-0,75^{\star}$ \\
\hline 16 & 18 & Clear signs indicating reception, parking, etc. & 2,70 & 2,73 & $+0,03$ \\
\hline 17 & 17 & Clean and attractive waiting room & 2,56 & 2,68 & $+0,12$ \\
\hline 18 & 12 & Availability of substitute transport & 2,48 & 1,87 & $-0,61^{2}$ \\
\hline 19 & 11 & Conveniently close to work & 2,30 & 2,22 & $-0,08$ \\
\hline 20 & 13 & Regular reminder/maintenance notices & 2,05 & 1,71 & $-0,34^{2}$ \\
\hline 21 & 10 & Conveniently close to home & 2,01 & 1,93 & $-0,08$ \\
\hline
\end{tabular}

asignificant at $P<0,05$.

${ }^{b}$ A negative coefficient in column $C$ indicates that the importance rating exced the performance rating regarding that particular attribute and vice verca. 
Table 6 importance and performance ratings of attributes: Customers of independent workshops

\begin{tabular}{lrlccc}
\hline & & $\begin{array}{c}\text { Mean } \\
\text { importance } \\
\text { rating } \\
\text { (A) }\end{array}$ & $\begin{array}{c}\text { Mean } \\
\text { performance } \\
\text { rating } \\
\text { (B) }\end{array}$ & \begin{tabular}{c} 
Difference \\
\cline { 3 - 5 }
\end{tabular} & $\begin{array}{c}\text { b) } \\
\text { (A) }\end{array}$ \\
\hline 1 & 9 & Honesty - work indicated as completed must be completed & 3,95 & 3,06 & $-0,89^{*}$ \\
2 & 1 & Job done right the first time & 3,88 & 2,86 & $-1,02^{*}$ \\
3 & 8 & Reasonable prices & 3,64 & 2,61 & $-1,03^{*}$ \\
4 & 2 & Fast response to complaints & 3,60 & 3,04 & $-0,56^{*}$ \\
5 & 20 & Availability of an informative account & 3,58 & 3,10 & $-0,48^{*}$ \\
6 & 6 & Vehicle ready when promised & 3,58 & 2,97 & $-0,61^{*}$ \\
7 & 19 & Informed in time of overnight stay & 3,44 & 2,95 & $-0,49^{*}$ \\
8 & 7 & Perform only necessary work & 3,42 & 3,06 & $-0,36^{*}$ \\
9 & 14 & Accurate quotations & 3,40 & 2,71 & $-0,69^{*}$ \\
10 & 16 & Availability of spare parts & 3,37 & 2,52 & $-0,85^{*}$ \\
11 & 4 & Service available when needed & 3,35 & 2,98 & $-0,37^{*}$ \\
12 & 5 & Courteous and friendly service & 3,29 & 3,35 & $+0,06$ \\
13 & 3 & Able to do any job needed & 3,29 & $-0,38^{*}$ \\
14 & 15 & Fast service on minor repairs & 3,19 & 2,81 & $-0,10$ \\
15 & 21 & Personal contact with mechanic & 3,19 & 3,09 & $+0,26$ \\
16 & 17 & Clean and attractive waiting rooms & 3,00 & 3,26 & $-0,01$ \\
17 & 18 & Clear signs indicating reception, parking, etc. & 2,41 & 2,40 & $+0,04$ \\
18 & 12 & Availability of substitute transport & 2,40 & 2,44 & $-0,55^{*}$ \\
19 & 10 & Conveniently close to home & 2,27 & 1,72 & $+0,60^{*}$ \\
20 & 11 & Conveniently close to work & 2,26 & 2,86 & $+0,37$ \\
21 & 13 & Regular reminder/maintenance notices & 2,03 & 2,40 & $-0,50^{*}$ \\
\hline
\end{tabular}

Significant at $P<0,05$.

${ }^{b}$ A negative coefficient in column $\mathrm{C}$ indicates that the importance rating exceed the performance rating regarding that particular attribute, and vice versa.

'The only instance where performance exced importance and the difference is significant at the $P<0,05$ level.

seem to indicate that independent workshops also do not fully satisfy the requirements of their customers.

\section{Advantages of an importance-performance analysis}

An importance-performance analysis is a useful technique for evaluating the elements of a marketing programme. A feature thereof is that results can be graphically displayed on a twodimensional grid, which facilitates the interpretation of information (Martilla \& James, 1977). Using a multi-dimensional scaling technique the information contained in Tables 5 and 6 regarding both respondent groups can be plotted as shown in Figures 1 and 2 respectively. Although the positioning of the axes and the naming of quadrants are based on subjective judgement it does give a clear indication of the attributes on which management will have to concentrate its efforts.

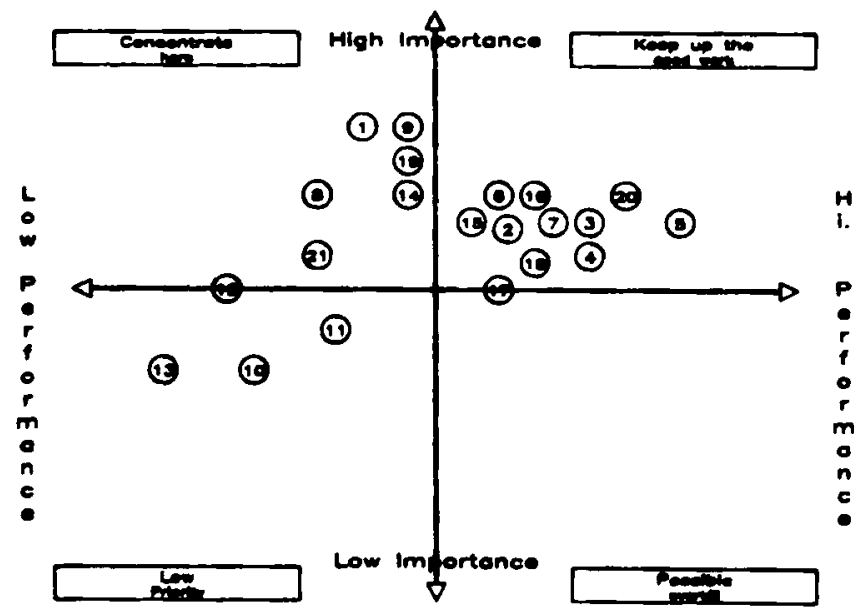

Fure 1 Importance-performance grid: Customers of franchised denlershins.
Figure 1 identifies the attributes that require the attention of the management of franchised dealerships, namely those located in the top, left quadrant. They are:

1. Job done right the first time.

8. Reasonable prices.

9. Honesty - work that is said to be completed, must be completed.

19. Informing customers in good time if vehicle must stay overnight.

14. Accurate quotations.

21. Personal contact between customer and mechanic who is responsible for repairing his vehicle.

Compared to Figure 1, Figure 2 shows the degree to which independent workshops are more successful with regard to satisfying the requirements of their customers. They have, for

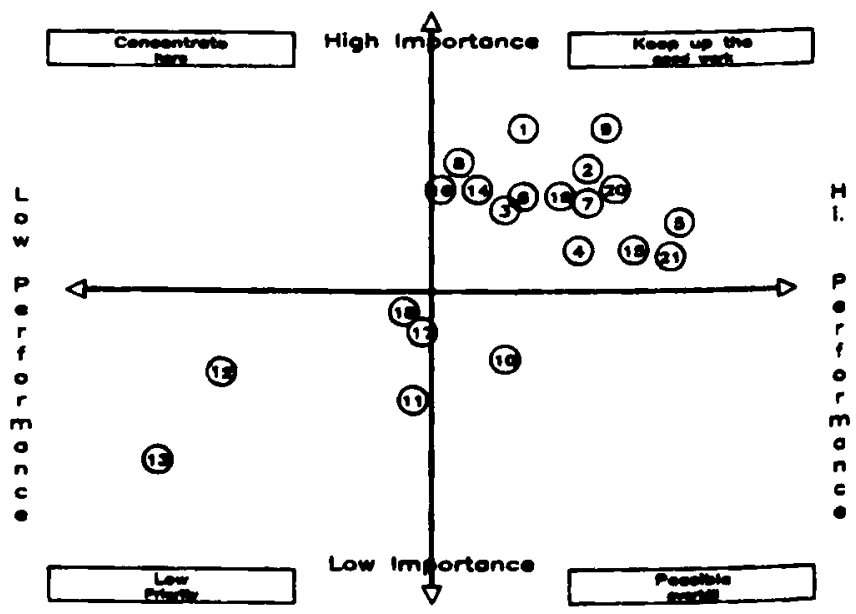

Figure 2 Importance-performance grid: Customers of independent workshops. 
instance 15 attributes in the quadrant termed 'Keep up the good work', compared to the 11 of franchised dealerships. Furthermore, franchised dealerships have six attributes in the quadrant termed 'Concentrate here' compared to the independent workshops, who have none.

\section{Managerial implications}

Although these findings are the result of an isolated study the managerial grid can be used, by the management of franchised dealerships in particular, to identify attributes whose performance should be improved. It also identifies attributes that may be consuming too many resources.

\section{Possible limitations}

Reliability is limited by sample size in any research that does not measure the entire population (Richardson \& Fogg: 217). As the sample was drawn from one geographical area only, certain methodological questions could be raised. Two further limitations are the possibility that only dissatisfied consumers in the sample responded and the low response rates of certain questions (see Table 2). Furthermore, the possibility exists that important attributes of a motor repair service were omitted.

\section{Summary of findings}

The most important finding of this study is that independent workshops perform certain important attributes of a motor repair service better than franchised dealerships do.

These attributes are:

personal contact with mechanic; job done right the first time; informed in time if vehicle must stay overnight; reasonable pricing; fast service on minor repairs;

fast response to complaints;

honesty - work indicated as completed, must be completed; vehicle ready when promised; and

courteous and friendly service.

It was also established that neither franchised dealerships nor independent workshops fully satisfy market requirements, although the latter's performance appears to be superior.

\section{Notes}

1. Confidential discussions with the Marketing Directors of two motor manufacturers.

2. Same sources as in note 1 .

3. An attribute rated important on the questionnaire was assigned a value of three.

\section{References}

Berdie, D.R. \& Anderson, J.F. 1976. Mail Questionnaire Response Rates: Updating Outmoded Thinking. J. Mark., vol. 40, January, $71-80$.

Crandall, R.W. 1970. The Decline of the Franchised Dealer in the Automobile Repair Market. J. Bus., vol. 43, January, $19-30$.

Martilla, J.A. \& James, J.C. 1977. Importance-Performance Analysis. J. Mark., January, 77-79.

Moyer, M.S. \& Whitmore, N.M. 1976. An Appraisal of the Marketing Channels for Automobiles. J. Mark., vol. 40, July, $35-40$.

Pretorius, S.G. 1973. 'n Bedryfsekonomiese Studie van die Motorhandel in Bloemfontein, met spesiale verwysing na Agentskaphouers. Unpublished M.Com. dissertation, University of the Orange Free State, Bloemfontein, 1973, 143 p.

Richardson, L. \& Fogg, D.N. 1970. Service Patronage Patterns and new Product Warranties: A Pilot Study of Automobiles. $J$. Bus. Res., July, 213 - 217. 